\title{
CREATING REVENUE OUT OF GREEN WASTE: NEW PERSPECTIVES FOR MUNICIPAL ORGANIC WASTE HARVESTING IN GEELONG, AUSTRALIA
}

\author{
Murray Herron ${ }^{1,2}$, David S. Jones ${ }^{3,4{ }^{*}}$, Phillip B. Roös' ${ }^{1}$, Zaheer Allam ${ }^{1}$ \\ 'Live+Smart Research Laboratory, Deakin University, Gheringhap Street, Geelong, 3220 Australia \\ ¿University of Tasmania, Invermay Road, Launceston, 7248, Australia \\ ${ }^{3}$ Wadawurrung Traditional Owners Aboriginal Corporation, Geelong, 3220 Australia \\ ${ }^{4}$ Cities Research Institute, Griffith University, Nathan, 4111, Australia \\ *Corresponding author: davidsjones2020@gmail.com \\ Received: November 20 ${ }^{\text {th }}, 2020$ / Accepted: February 16 ${ }^{\text {th }}, 2021$ / Published: April $1^{\text {st }}, 2021$ \\ https://DOI-10.24057/2071-9388-2020-182
}

\begin{abstract}
The diversion and recovery of organic waste are one of the most significant opportunities and challenges for reducing the environmental impacts of waste disposal internationally, as recognised by the United Nations'SDG 12 that seeks to "ensure sustainable consumption and production patterns". This issue is particularly pertinent to developed countries, like Australia, who have a high propensity for waste removal arising from their industrial and domestic use of products, materials and organic consumables. Through the use of GIS technology, using modelling software developed by the Global Methane Initiative, a series of simulations were undertaken to determine the viability of an anaerobic digester for the City of Greater Geelong (COGG), located in the State of Victoria (Australia), where organic materials constitute over 25\% of all waste land-filled. Using only municipal organic waste, the modelling concluded that the COGG would generate between AU\$6MAU\$1 1M/annum from the sale of biogas/methane. In addition to this revenue stream, COGG would have an Annual Projected Net Emissions Reductions of 3797 Mt. This paper further considers the development of a geospatial database to identify and locate concentrated organic waste resources in COGG, the design and development of a software tool to help quantify the production of food waste, and the development of an economic model to value the organic waste stream of COGG arising from the implementation of this proposal.
\end{abstract}

CITATION: Murray Herron, David S. Jones, Phillip B. Roös, Zaheer Allam (2021). Creating Revenue Out Of Green Waste: New Perspectives For Municipal Organic Waste Harvesting In Geelong, Australia. Geography, Environment, Sustainability, Vol.14, No 1, p. 91-105 https://DOl-10.24057/2071-9388-2020-182

ACKNOWLEDGEMENTS: While no funding underpins this research the authors wish to thank the contributions from the Live+Smart Research Laboratory and the Barwon South West Waste and Resource Recovery Group in Geelong.

Conflict of interests: The authors reported no potential conflict of interest.

\section{INTRODUCTION}

Internationally we are drowning in a sea of waste, both on land and in our waters (Allam \& Jones 2018). In 2018 the World Bank concluded, on current patterns, that global waste will increase by $70 \%$ by 2050 . The Bank pointed to its escalation due to rapid urbanization and growing populations and projected that global annual waste generation is expected to increase to 3.4 billion tonnes over the next 30 years, up from 2.01 billion tonnes in 2016 (Kaza et al. 2018).

Portently, it was developed countries, despite only comprising $16 \%$ of the world's population, generated more than one-third (34\%) of the world's waste. Frightening, it was the East Asia and Pacific region, including Australia, that was responsible for generating close to a quarter (23\%) of all global waste. The World Bank concluded that 'solid waste management is critical for sustainable, healthy, and inclusive cities and communities, yet it is often overlooked, particularly in low-income countries' noted that 'while more than one-third of waste in high-income countries is recovered through recycling and composting, only $4 \%$ of waste in low-income countries is recycled' (Kaza et al. 2018). Of this, some 1.6 billion tonnes of carbon-dioxideequivalent were generated in 2016 from the treatment and disposal of waste in 2016 comprising 5\% of global emissions. The World Bank concluded that quality waste management systems are essential 'to building a circular economy, where products are designed and optimized for reuse and recycling'(Kaza et al. 2018). With local, national and or international acceptance of a circular economy, smart and sustainable ways to manage waste will thereupon help promote efficient economic growth while minimizing environmental impact.

Waste volume, particularly originating from developed countries, exponentially mirrors population and gross domestic product growth in these countries. Their historical approach has been to capture the majority of these wastes, and to hide them, often with due diligence and care but often with little regard to the environmental venue of 'disposal' and 'treatment'.

Hidden in all this is green waste, the organic wastes of food, garden, timber, textiles and paper all derived from our normal household and industrial processes, packaging, 
and fabrication processes. But more deeply hidden within 'green wastes' are the results of our scouring of the landscape to enable urbanisation and thereupon our aesthetic predilection to plant trees in these landscapes as well as clip, mow, and maintain these new landscapes as well as the established urban landscapes that we retrofit green into.

\section{Sustainable development goals for organic waste}

Turning to the United Nations'Sustainable Development Goals (SDGs). The SDGs comprise 17 global-based goals intended to offer a "blueprint to achieve a better and more sustainable future for all", and were adopted by the United Nations General Assembly in 2015 (United Nations 2020). Associated with each Goal is a set of targets, varying between 8-12 in total with 1-4 indicators each target, to enable performance measurement of the target achievement, that is intended to be achieved by the year 2030 (United Nations 2016).

In terms of organic waste, its scope is primarily contained within SDG Goal 12 that seeks to "Ensure sustainable consumption and production patterns" although, to a lesser extent, Goal 11 that states "Make cities and human settlements inclusive, safe, resilient and sustainable" is also relevant (United Nations 2016). These relevant goals, their targets and their indicators are quoted in Table 1.

Overall, SDG 12 seeks (i) a change of global activities towards using eco-friendly production methods and reducing the amount of waste; (ii) that by 2030 national recycling rates should increase, as measured in tons of material recycled; and (iii) that companies should adopt sustainable practices and publish sustainability reports. More importantly, Target 12.1 seeks the development and execution of the 10-Year Framework of Programmes on Sustainable Consumption and Production to scaffold avenues towards sustainable consumption and production in developed and developing countries (United Nations 2016).
Against this backdrop, this paper seeks to explore the potential of green waste as an avenue for additional revenue generation. The paper concentrates upon the City of Greater Geelong Council (COGG), a city in Australia, as a case study. It showcases, how, that instead of 'shrewdly hiding' the costs of wastes in municipal budgets, this could be exploited to allow municipals with an added revenue stream while helping in reducing emissions, creating employment opportunities and opening new avenues for the economic growth of the city. In this regard, this study outlines the development of databases that could be used, the tools (especially software) that could help in quantifying the production of the green waste and thereafter, develop an economic model that could guide the revenue creation from waste generated in COGG.

\section{Materials: contemporary context and literature}

Australia, as an exemplar of green waste 'production' has taken little forthright care in its policies and practices to creatively recycle, reuse or reconstitute green waste less except in plastics and paper. Domestic, commercial and industrial food wastes more often end up in rubbish bins, with only a small percentage being recycled or recirculated into poverty initiatives. Garden wastes, that include soil, lawns, trees, plants, etc., both their hard forms as well as clippings and masse removal to service urbanisation expansion or to service major excavations associated with infrastructure projects, is little discussed unless the soil is contaminated. Green waste includes are organic waste streams that predominately originate from our supermarkets, kitchens, dairies, vegetable, abattoirs and fisheries wastes, to grain and legume surpluses, and include our ordinary common domestic garden waste without even mentioning all the green waste generated by local municipalities in their day-to-day municipal maintenance operations. Timber waste is similarly hidden in landfill which is in stark contrast to the major commercial exotic and native species plantations in Australia that service the

Table 1. Sustainable Development Goals, Targets and Indicators pertinent to organic waste

\begin{tabular}{|c|c|c|}
\hline Goal & Goals and targets (from the 2030 Agenda) & Indicators \\
\hline $\begin{array}{l}\text { Goal 11. Make cities and human settlements } \\
\text { inclusive, safe, resilient and sustainable }\end{array}$ & $\begin{array}{l}11.6 \text { By } 2030 \text {, reduce the adverse per capita } \\
\text { environmental impact of cities, including by } \\
\text { paying special attention to air quality and } \\
\text { municipal and other waste management }\end{array}$ & $\begin{array}{l}\text { 11.6.1 Proportion of urban solid waste } \\
\text { regularly collected and with adequate final } \\
\text { discharge out of total urban solid waste } \\
\text { generated, by cities }\end{array}$ \\
\hline \multirow[t]{4}{*}{$\begin{array}{l}\text { Goal 12. Ensure sustainable consumption } \\
\text { and production patterns }\end{array}$} & $\begin{array}{l}12.3 \text { By } 2030 \text {, halve per capita global food } \\
\text { waste at the retail and consumer levels and } \\
\text { reduce food losses along production and } \\
\text { supply chains, including post-harvest losses }\end{array}$ & 12.3.1 Global food loss index \\
\hline & $\begin{array}{l}\text { 12.4 By } 2020 \text {, achieve the environmentally } \\
\text { sound management of chemicals and } \\
\text { all wastes throughout their life cycle, in } \\
\text { accordance with agreed international } \\
\text { frameworks, and significantly reduce their } \\
\text { release to air, water and soil in order to } \\
\text { minimize their adverse impacts on human } \\
\text { health and the environment }\end{array}$ & $\begin{array}{l}\text { 12.4.1 Number of parties to international } \\
\text { multilateral environmental agreements on } \\
\text { hazardous waste, and other chemicals that } \\
\text { meet their commitments and obligations in } \\
\text { transmitting information as required by each } \\
\text { relevant agreement }\end{array}$ \\
\hline & & $\begin{array}{c}\text { 12.4.2 Hazardous waste generated per capita } \\
\text { and proportion of hazardous waste treated, } \\
\text { by type of treatment }\end{array}$ \\
\hline & $\begin{array}{c}12.5 \text { By } 2030 \text {, substantially reduce waste } \\
\text { generation through prevention, reduction, } \\
\text { recycling and reuse }\end{array}$ & $\begin{array}{l}\text { 12.5.1 National recycling rate, tons of } \\
\text { material recycled }\end{array}$ \\
\hline
\end{tabular}


woodchipping industry (often being felled in Australia, shipped to Japan, and re-shipped back to Australia), or in their harvesting for commercial housing framing and associated domestic products (Frontier et al. 2018).

Waste is visibly hidden from the public arena, by both local municipal and state governments, as well as by private storage or recycling operations. So it is quite remarkable that: few in the community know about the numerous tip trucks from Sydney that thread their way north daily often into Queensland for dumping purposes carving their weight into nationally-paid for highway pavements; or, that hidden inside many derelict large warehouses in metropolitan Sydney or Melbourne are highly combustible venues of chemical, toxic, rubber, paper, plastic, etc., waste just waiting to ignite and cause major toxic fires and leakages into creek systems in conjunction with fire suppressant chemicals (Vedalgo et al.); or, that Melbourne's major new underground rail (Metro Tunnel 2019), and freeway tunnel (Victoria 2020a) projects are desperately seeking venues to host vast metric tons (Mt) of clean, clean/contaminated mix, and or contaminated soil within one-hour driving distance of their excavation sites.

Carey (2017) has written that, in Victoria,

Decaying food that emits greenhouse gases as it rots; shredded old cars and white goods that can't be recycled; vast quantities of construction spoil; discarded televisions and computers that if mishandled could leach harmful chemicals into the environment. ... Victorians produced 12.8 million tonnes of rubbish in 2015-16, ... [and that rubbish is] projected to generate more than 20 million tonnes of waste each year by 2043 ... [that] will cost between $\$ 3.6$ billion and $\$ 5$ billion in the next 30 years to manage the increase in waste and improve the state's recycling regime so that less rubbish goes to landfill. About two-thirds of the 12.8 million tonnes of waste was recycled, ... with the remaining third going to landfill. On that projection, the giant waste pile will grow by about 240,000 tonnes a year'.

In Victoria, organic materials (food, garden, timber, textiles and paper) typically constitute approximately 50\% of household garbage by weight, some $25-30 \%$ of industrial waste, and comprise over $25 \%$ of all waste 'dumped' in landfill venues. What is additional hidden from the public, is the real and high financial and environmental costs of managing these wastes, and that this cost is predominantly borne by local municipalities and budget-translated to public quietly inside their local government rates. What was once the core functions of Australian local governance was 'roads, rates and rubbish' has now increasingly become 'roads, rates and Rubbish' with a capital P for 'Planning' that is little accepting responsibility to redress or innovate the latter.

While there is private and public sector research into this problem, and attempts to innovate, translating such recycling-related ideals into practice is slow and lacks vision. This is more so unless the private sector, like paper packaging, can see a \$ return from their investment in human resources and hard infrastructure to enable recycling profitably. A corporation like Visy, in Australia (Visy
2020) and the United States (Stensholt 2015; Stensholt 2017) evidence this pattern, but it one of a few venturing into the arena. More still, it is the green or organic waste arena that has had little innovations and creative strategies that include 'P's' involvement.

An exception to this observation is the Global Methane Initiative (GMI) (GMI 2020). The GMI is a voluntary, international collaborative that is seeking to change values by bringing together national governments, private sector entities, development banks, non-government organisations (NGOs) and other interested stakeholders in a partnership initiative towards reducing global methane gas emissions and advancing methane recovery and its use as a clean energy source. Established in 2004, GMI is now an international-level public-private initiative that seeks to enable and encourage cost-effective, near-term methane abatement and recovery, and reconstitution of methane as a clean energy source in three sectors: biogas (including in agriculture, municipal solid waste, and wastewater), in coal mines, and in oil and gas systems. Partners in GMl include many countries, like Australia, as well as the United Nations Economic Commission for Europe (UNECE) and the Climate and Clean Air Coalition to Reduce Short-Lived Climate Pollutants (CCAC) to reduce global methane emissions. At the crux of GMl's activities is a desire that promotes methane emission sources as an alternate and cost-effective approach to reducing global greenhouse gas (GHG) emissions and to increase global energy security, enhance economic growth, to improve air quality and to improve worker safety.

From 2015 through 2030, Global Non- $\mathrm{CO}_{2}$ Greenhouse Gas Emission Projections are projected to decrease by about 6\% to approximately $912 \mathrm{MtCO}_{2} \mathrm{e}$ in 2030. Internationally, the top 5 emitting countries projected for 2030 are China (625 MMTCO e), Russia (57 MMTCO e), United States (45 $\mathrm{MMTCO}_{2} \mathrm{e}$ ), India (27 $\mathrm{MMTCO}_{2} \mathrm{e}$ ) and Australia $\left(24 \mathrm{MMTCO}_{2} \mathrm{e}\right)$ with the rest of the world coming in at $133 \mathrm{MMTCO}_{2}$ e. $\mathrm{MMTCO}_{2}$ e in million metric tonnes of carbon dioxide equivalent (EPA 2015).

For Australia, the current and 2020-2050 projected methane emissions, set out in Table 2, presented in million metric tonnes carbon dioxide equivalent $\left(\mathrm{MMTCO}_{2} \mathrm{e}\right)$, is quite staggering.

A key to green waste conversion is Anaerobic digestion. Anaerobic digestion is a process that converts commercial and industrial green waste into on-site electricity, heat and clean methane gas. The digestion involves a sequence of processes by which microorganisms break down biodegradable material in the absence of oxygen. This process is already used in our industrial or domestic activities as a strategy to manage waste or to produce fuels, of which the former involves the conventional fermentation strategy that used industrially to produce food and drink products, as well as home fermentation Matsakas et al. 2014). Additionally, anaerobic digestion occurs naturally in some soils and in lake and oceanic basin sediments, when earth scientists talk about "anaerobic activity".

Table 2. Australia's 2020 current and 2020-2050 projected methane emissions

\begin{tabular}{|c|c|c|c|}
\hline Sector & 2020 & 2035 & 2050 \\
\hline Oil \& Gas & 12.964 & 15.497 & 21.105 \\
\hline Coal Mines & 23.960 & 23.960 & 22.463 \\
\hline Biogas & 13.807 & 15.261 & 16.778 \\
\hline Totals & 50.731 & 50.731 & 54.718 \\
\hline
\end{tabular}

Source: EPA 2020; GMI 2020 
Scientifically, the digestion process begins with bacterial hydrolysis of the input materials. Through hydrolysis, insoluble organic polymers, such as carbohydrates, are broken down into soluble derivatives that become available for other host bacteria. For example, Acidogenic bacteria will convert sugars and amino acids into carbon dioxide, hydrogen, ammonia, and organic acids. Thus, the hydrolysis process causes a chemical reaction whereby particulates are solubilized and large polymers converted into simpler monomers (Duan et al. 2018). In Acetogenesis, bacteria convert these resulting organic acids into acetic acid, along with additional ammonia, hydrogen, and carbon dioxide (Schuchmann and Müller 2016). Thus, Acetogenesis is a process by which acetate is produced either by the reduction of organic acids or by the reduction of $\mathrm{CO}_{2}$. In the final digestion step, methanogens convert these products into methane and carbon dioxide. The methanogenic archaea populations, microorganisms that produce methane as a metabolic by-product in hypoxic conditions, perform a key role in anaerobic wastewater treatments. The latter is the normal way we treat and process biodegradable waste and sewage sludge on our sewerage 'farms' like the Melbourne Treatment Farm south-west of metropolitan Melbourne (Melbourne Water 2020). As part of its integrated waste management system, anaerobic digestion processes on this Farm naturally emit landfill gas emissions into the atmosphere.

Internationally, anaerobic digestion underpins our human desire to re-use waste as a resource aided by new technological approaches that have lowered capital costs. Thus, countries like United Kingdom, Germany, Denmark, and the United States, have shown increased commercial and non-commercial policy interest this realm but in terms of the 'green' act of recycling but more important in its potential as a renewable energy source. Because the anaerobic digestion process produces biogas, that consists of methane, carbon dioxide, and traces of other 'contaminant' gases, this biogas can be used directly as fuel in combined heat and power gas engines or reconstituted into natural gas-quality biomethane (Prussi et al. 2019). A lesser use, to date, is the use of the nutrient-rich digestate as a fertilizer for soil renewal and the cultivation of grain cereals and herbaceous species.
A further aspect to recognise is that there are waste hierarchy priorities:

1. Avoidance including action to reduce the amount of waste generated by households, industry, and all levels of government

2. Resource recovery including re-use, recycling, reprocessing, and energy recovery, consistent with the most efficient use of the recovered resources

3. Disposal including management of all disposal options in the most environmentally responsible manner.

\section{STUDY AREA}

To the south-west of metropolitan Melbourne, in Victoria, is the regional centre and region of Geelong and the Bellarine Peninsula presently hosting a growing community of over 500,000 permanent and transitory residents. Historically, Geelong was the heavy industrial corner-stone of Melbourne hosting numerous rust belt industries including Vterra, Ford, Alcoa, but global transformations have ceased much of these operations, and Geelong is increasingly engaging in health insurance, animal biosecurity, education, new carbon fibre technologies and digital innovation industries (Jones and Roös 2019). For this region, the Barwon South West Waste and Resource Recycling Group (BSWWRRG) (Barwon Waste Recovery) is responsible for facilitating an integrated approach to waste-related regional planning, and for the delivery of waste management and resource recovery services that align with state-wide waste and resource recovery planning for all municipalities located in the south-west region of Victoria that stretches from Geelong to Warrnambool to the South Australian state border (BSWWRRG 2017; BSWWRRG 2020).

The Barwon Waste Recovery works with nine municipal councils: (Figure 1): Borough of Queenscliffe, City of Greater Geelong, Colac Otway Shire Council, Corangamite Shire Council, Glenelg Shire Council, Moyne Shire Council, Southern Grampians Shire Council, Surf Coast Shire Council, and the Warrnambool City Council.

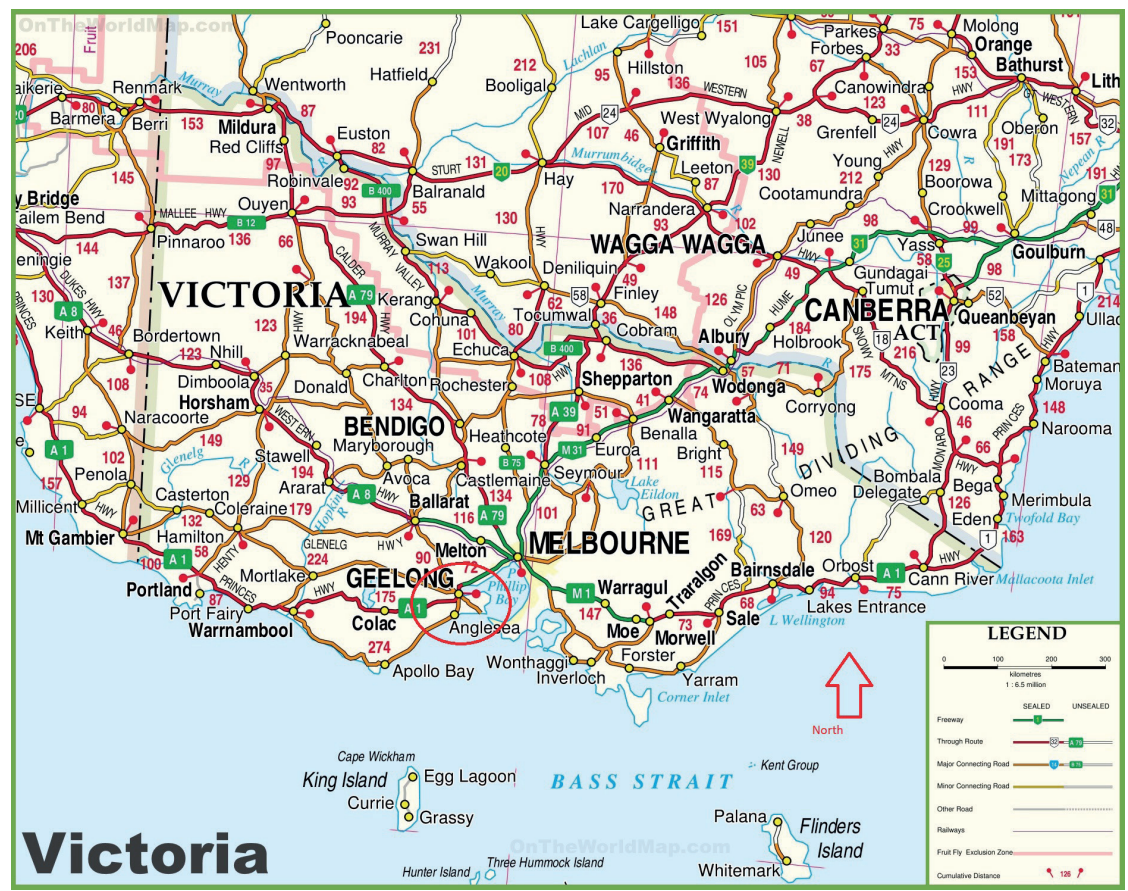

Fig. 1. Barwon South West Waste and Resource Recycling Group Area Source: BSWWRRG 2017 
The Barwon Waste Recovery was established in 2014 under the Environment Protection Act 1970 (Vic) (Victoria 1970), which sets out the objectives, functions and powers of a waste recovery group (BSWWRRG 2018). The statutory objectives of a Waste and Resource Recovery Group, under Clause 49G of the Act (Victoria 1970), are:

1. to undertake waste and resource recovery infrastructure planning to meet the future needs of its waste and resource recovery region while minimising the environmental and public health impacts of waste and resource recovery infrastructure;

2. to facilitate efficient procurement of waste and resource recovery infrastructure and services for its waste and resource recovery region through the collective procurement of waste management facilities and waste and resource recovery services in the region;

3. to integrate regional and local knowledge into statewide waste and resource recovery market development strategies; 4. to educate businesses and communities within its waste and resource recovery region to reduce waste going to landfill by using waste and resource recovery infrastructure and services efficiently; and

5. to ensure Regional Waste and Resource Recovery Implementation Plans and programs are informed by local government, business and community and inform statewide waste and resource recovery planning and programs.

6. In seeking to achieve its objectives, a Waste and Resource Recovery Group must collaborate with councils, Sustainability Victoria, the Authority, industry, business and the community.

The statutory functions of a Waste and Resource Recovery Group, defined under Clause $49 \mathrm{H}$ of the Act (Victoria 1970), are:

1. to plan for the future needs of waste and resource recovery infrastructure within its waste and resource recovery region consistently with the statewide Waste and Resource Recovery Infrastructure Plan;

2. to facilitate the provision of waste and resource recovery infrastructure and services by councils within its waste and resource recovery region;

3. to facilitate the development of contracts for the joint procurement of waste management facilities and waste and resource recovery services within its waste and resource recovery region;

4. to manage contracts in the performance of its objectives and functions;

5. to work with Sustainability Victoria, councils, businesses and communities to ensure statewide waste and resource recovery education programs are adapted to the needs of its waste and resource recovery region and to facilitate the delivery of those education programs;

6. to advise, with Sustainability Victoria, councils and businesses within its waste and resource recovery region on best practices for waste and resource recovery systems, facilities and services;

7. to support its waste and resource recovery region's Local Government Waste Forum to enable the Waste Forum to perform its functions; and

8. to undertake waste and resource recovery projects as funded by government, councils and other organisations.

Barwon Waste Recovery is one of seven statutory authorities in Victoria set up under the Environment Protection Act 1970 (Vic) to facilitate a coordinated approach to the planning and delivery of infrastructure and services for waste reduction and recycling (Victoria 1970). As a vision, Barwon Waste Recovery seeks to 'find innovative ways to reduce and recycle waste and plan for the future waste and recycling needs of the Barwon South West'. It does this by working closely with nine local municipalities as well as local businesses and the community to achieve its vision of being a leader in waste minimisation and resource recovery. It actions this vision by gathering knowledge and data about what is happening with recycling and waste; ensuring that there are enough facilities and processors to handle recycling and waste in Barwon South West; providing advice on recycling and waste issues; working with the community to reduce, reuse and recycle waste; working with local municipalities to improve recycling and waste services for their communities; supporting local municipalities to work together on recycling and waste initiatives; investigating new and interesting ways to turn waste from a problem material into a resource; connecting the makers of waste with processors to help them find new ways to reduce and recycle; and, assisting groups to obtain funding for waste reduction and recycling activities (Barwon Water 2020).

To enable this vision, the Barwon Waste Recovery has a Barwon South West Waste and Resource Recovery Implementation Plan 2017-2026 (BSWWRRG 2017). Consideration of the Victorian Guide to biological recovery of organics (Victoria 2018) and the Victorian Recycled Organics Market Analysis (Victoria 2013) are also applicable in this discussion.

In this paper we focus specifically on the City of Greater Geelong which is the largest local government area in the BSWWRRG. The municipality has jurisdiction for a land area of 1,248 $\mathrm{km}^{2}$ and, in June 2018, had a population of 252,217. Between 2016 and 2041, the population for the City of Greater Geelong is forecast to increase by 153,685 persons (64.16\% growth), at an average annual change of $2.00 \%$.

Using available data, Table 3 provides based upon estimates of generation, recovery and landfilling of organics, based on the Barwon South West Waste and Resource Recovery Implementation Plan (BSWWRRG, 2017) and data sourced by Blue Environment (2020).

Table 3. Organics management in the Barwon Waste Recovery Region

\begin{tabular}{|c|c|c|c|}
\hline Organics category & Generated & Landfilled & Recovered \\
\hline Food & $40,000-45,000$ & $35,000-40,000$ & $>5,000$ \\
\hline Garden and garden and food & $55,000-65,000$ & $10,000-15,000$ & $45,000-55,000$ \\
\hline Wood/timber & $30,000-40,000$ & $15,000-20,000$ & $10,000-20,000$ \\
\hline Biosolids (to agriculture) & 95,000 dried tonnes & nil & 95,000 dried tonnes \\
\hline Other biodegradable organics & $20,000-25,000$ & 500 & $20,000-25,000$ \\
\hline Organics imported from outside the region & - & - & $10,000-20,000$ (mainly timber) \\
\hline Organics exported out of the region & $15,000-30,000$ & $10,000-20,000$ & $5,000-10,000$ \\
\hline
\end{tabular}

Source: Blue Environments 2020, 3. 
Table 3 demonstrates that there are:

a) low levels (<13\% by weight) of food waste recovery with a high proportion of food remaining in municipal and commercial putrescible waste;

b) that there are high levels of garden organics recovery, mainly due to the provision of kerbside garden organics (GO) and food organics and garden organics (FOGO) services across most of the region, and that this is expected to increase as partner municipalities implement FOGO services or promote on-site management of food organics; and,

c) that there are moderate levels of recovery of timber waste through formal waste management pathways recognising that unknown but significant amounts of timber are managed through informal pathways.

\section{METHODS}

To better understand the future residential, commercial and industrial growth patterns in the City of Greater Geelong area (COGG) and their corresponding impacts on the Geelong regional environment, a residential, commercial and industrial Build-Out was undertaken. A Build-Out projects the number, location and appearance of buildings based upon extant land use or urban planning zoning information. The build-out analysis was performed using CommunityViz (CommunityViz 2020), a geographic information systems (GIS) planning and simulation software package (Herron et al. 2015). The software allows the users to set density assumptions in dwelling units per ha, as well as minimum lot size or floor area ratio. In addition, while there are default values, users can also assign design assumptions, including layout efficiency, building offsets, development constraints, layout patterns and building types into the excel-based variables.

The results of the CommunityViz-derived build-outs include indicator charts that summarize the building counts or impacts, point shapefiles depicting building locations with attributes, and real-time visualizations of the buildings in 3D realistic models in context with the community (Herron et al. 2015). It also allows planners to factor in future scenarios since the build-out analysis providesan overview on the maximum number ofbuildings that a given area could comfortably accommodate, based on the existing zoning and land use regulations. In the case here, the adoption of the CommunityViz built-out analysis will also allow the determination of the remaining capacity in the City of Greater Geelong and this will help in estimating the expected future waste generation. Hence, the tools and economic model that could be adopted for turning green waste into a revenue-generating venture will manage to capture such future expected changes. This would be possible as the built-out analysis helps in the determination of other issues such as building offsets, layout efficiency, layout patterns and development constraints among other things.

To develop economic, demographic and planning scenarios the Community Viz software performs four functions. These functions are:

1) estimation, statistical counting and location modelling of new developments allowed in an area according to current or proposed zoning regulations;

2) a suitability evaluation of the new development to a prescribed area(s);

3) the allocation and direction of where urban/building growth is most likely to occur over a specific determined or flexible period; and finally,

4) the development of a series of environmental indicators that can graphically and numerically depict the impact of the new development upon the landscape (Walker 2011).

This process is graphically summarised in Figure 2. The build-out analysis (Figure 3) summarises the residential, industrial, and commercial potential from 2016 through 2050 for COGG.

The buildout indicators developed show the future impacts including:

- Annual carbon (CO) Auto Emissions

- Annual carbon dioxide (CO2) Auto Emissions

- Annual Hydrocarbon Auto Emissions

- Annual nitrogen oxides (NOx) Auto Emissions

- Solid Waste Generation

- Residential Energy Usage

- Residential Water Usage

- Residential Dwelling Units

- School Children

To better translate the detail of the COGG municipal waste profile three new waste indicators were developed. The indicators were split into 1) municipal solid waste, 2) organic waste, and 3) recyclable waste.

\section{Major Tools}

Build-Out Wizard

Estimates the amount and location

of development allowed in an

area according to current or

proposed zoning regulations

Suitability Wizard

Specifies suitability or desirability analyses

Allocate Wizard

Determines where growth is most

likely to occur over time

Common / Custom Impacts Wizards Impacts associated with growth and development

\section{How it Works}

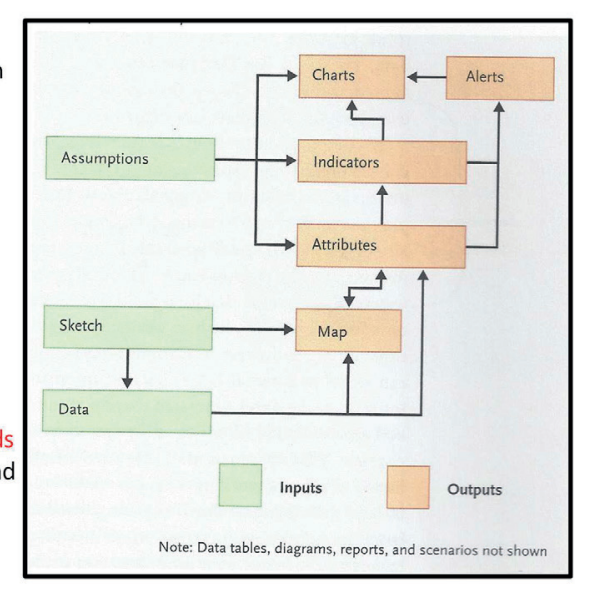

Source: Placeways LTD, 2013

Fig. 2. CommunityViz: How it Works. Source: Walker 2011 


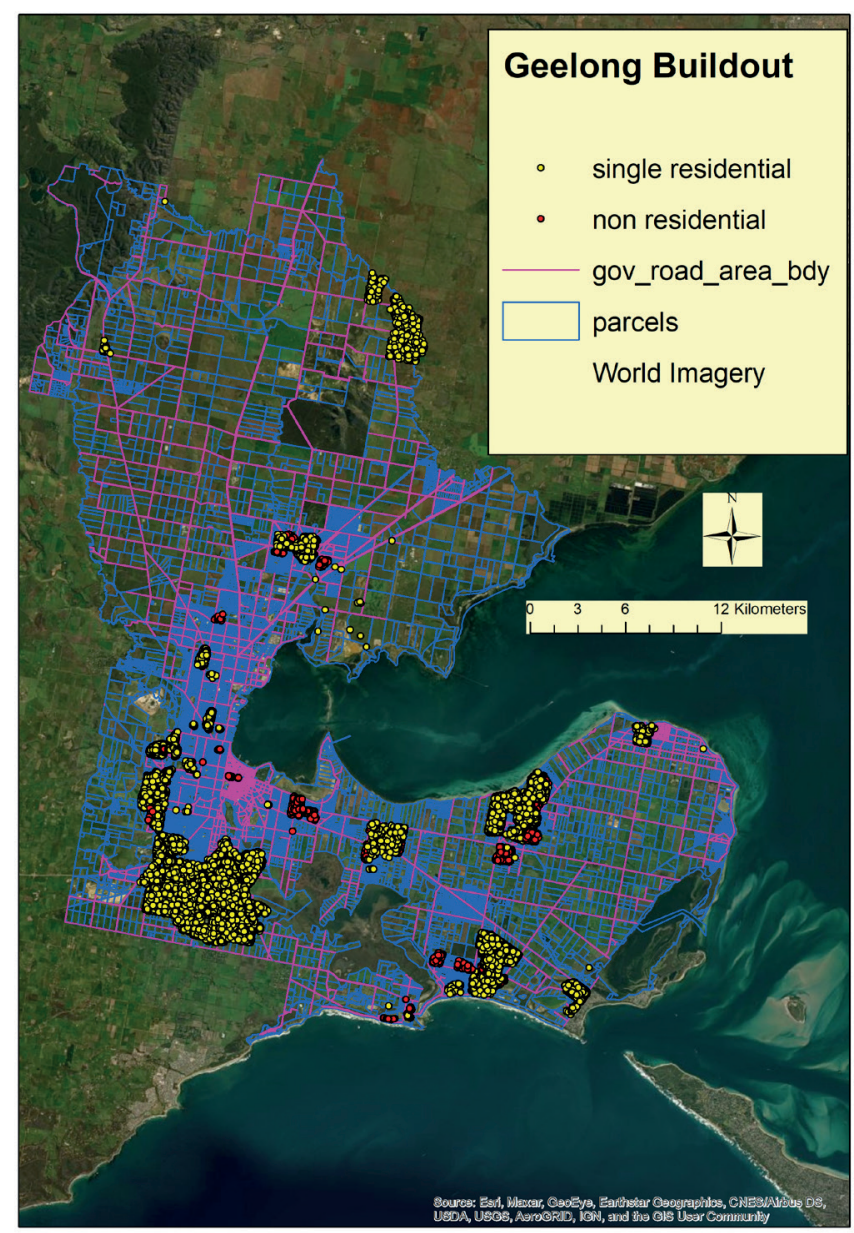

Fig. 3. Geelong Build-out Results.

The composition of municipal solid waste varies greatly from Australian municipality to municipality, and it changes significantly with time. In municipalities that have a well-developed waste recycling system, the municipal solid waste stream mainly consists of intractable wastes including plastic film and non-recyclable packaging materials. Organic waste consists of biodegradable waste: food and kitchen waste, green waste, paper (most can be recycled, although some difficult to compost plant material). Recyclable waste consists of recyclable materials: paper, cardboard, glass, bottles, jars, tin cans, aluminium cans, aluminium foil, metals, certain plastics, textiles, clothing, tires, batteries, etc.

In addition, the three waste indicators - 1) municipal solid waste, 2) organic waste, and 3) recyclable waste - were further segmented into daily, weekly, monthly and yearly results. This data, derived from this modelling and calculations based upon 2019 COGG waste data inventories, was individually reviewed and considered.

Initial benchmark data used for this GIS modelling was sourced from the Victorian government spatial data mart data website (Victoria 2020).

The detail statistics of the COGG waste profile and rubbish bin audit were developed by EC Sustainable of Sydney. EC Sustainable is a leading sustainability, waste and resource recovery consultancy operating across Australia that, in particular, have expertise in waste, sustainability and resource recovery strategies, waste plan development, and waste audits and recycling audits The rubbish bin audit included a visual bin survey/assessment and a physical audit of the municipal waste stream. Included in their audit are other forms of waste that can be similarly mapped and analysed. They include:

- Commercial waste consisting of waste from premises used mainly for the purposes of a trade or business or for sport, recreation, education or entertainment, but excluding household, agricultural or industrial waste.

- Industrial waste produced by industrial activity that includes any material that is rendered useless during a manufacturing process such as that of factories, industries, mills, and mining operations. Types of industrial waste include dirt and gravel, masonry concrete, scrap metal, oil, solvents, chemicals, scrap lumber, even vegetable matter from restaurants. Industrial waste may be solid, liquid or gaseous.

- Construction waste (including construction and demolition materials) that consists of unwanted material produced directly or incidentally by the construction or industries. Examples include building materials such as insulation, nails, electrical wiring, shingle, and roofing as well as waste originating from site preparation such as dredging materials, tree stumps, and rubble (EC Sustainability 2018).

\section{RESULTS}

The residential bin audit, depicted in Table 4, shows the nature and character of the waste stream, recycling stream, organic stream results for Geelong.

The residential waste profile for Geelong was segmented by volume per week and household. The segmentation took the form of eight classes of waste (i.e., i) paper, ii) organic, iii) glass, iv) plastic, v) metal, vi) hazardous, vii) building waste and viii) other). Tables 5 and 6 below depict the Geelong residual waste stream composition by volume. 
Table 4. Waste Generation across Geelong. Source: Victoria (2018)

\begin{tabular}{|c|c|c|c|}
\hline & Waste Stream - \% by weight & Recycling Stream - \% by weight & Organics Stream - \% by weight \\
\hline Paper & 8.7 & 51.3 & 0.5 \\
\hline Glass & 3.1 & 16.4 & 0.0 \\
\hline Plastics & 13.6 & 9.9 & 0.1 \\
\hline Steel & 1.4 & 2.5 & 0.0 \\
\hline Other non-ferrous & 1.0 & 1.4 & 0.0 \\
\hline Food & 34.0 & 0.7 & 0.2 \\
\hline Garden Organics & 8.5 & 0.0 & 97.7 \\
\hline Other Organics & 5.6 & 0.0 & 0.0 \\
\hline Hazardous & 3.4 & 0.2 & 0.0 \\
\hline Other & 20.6 & 15.3 & 1.5 \\
\hline
\end{tabular}

Table 5. Residual waste (good, garden organics, hazardous and other) stream composition for COGG.

Source: Abridged from EC Sustainability 2018, Tables 53, 84-85

\begin{tabular}{|c|c|c|c|c|c|c|c|}
\hline \multirow[t]{2}{*}{ Sorting Category } & & \multicolumn{3}{|c|}{ Weight (Kg/hh/wk) } & \multicolumn{3}{|c|}{ Percentage (\% by weight) } \\
\hline & & Waste & Recycling & Organics & Waste & Recycling & Organics \\
\hline \multirow{10}{*}{ Food } & Fruit and vegetables & 2.149 & 0.012 & 0.011 & 22.84 & 0.22 & 0.13 \\
\hline & Meat and seafood & 0.191 & 0.000 & 0.001 & 2.03 & 0.00 & 0.01 \\
\hline & Staples & 0.434 & 0.021 & 0.002 & 4.61 & 0.39 & 0.02 \\
\hline & Tea and coffee grinds & 0.041 & 0.000 & 0.000 & 0.43 & 0.00 & 0.00 \\
\hline & Eggshells & 0.115 & 0.000 & 0.000 & 0.43 & 0.00 & 0.00 \\
\hline & Dairy & 0.082 & 0.001 & 0.000 & 0.87 & 0.02 & 0.00 \\
\hline & Cooking oil & 0.007 & 0.000 & 0.000 & 0.07 & 0.00 & 0.00 \\
\hline & Confectionery & 0.017 & 0.000 & 0.001 & 0.18 & 0.00 & 0.01 \\
\hline & Meat meal leftovers & 0.164 & 0.004 & 0.000 & 1.74 & 0.07 & 0.00 \\
\hline & Sub-total & 3.199 & 0.038 & 0.014 & 34.00 & 0.70 & 0.17 \\
\hline \multirow{2}{*}{ Garden org. } & Garden / vegetation & 0.801 & 0.011 & 8.058 & 8.52 & 0.21 & 97.68 \\
\hline & Sub-total & 0.801 & 0.011 & 8.058 & 8.52 & 0.21 & 97.68 \\
\hline \multirow{3}{*}{ Other org. } & Compostable bag liners & 0.000 & 0.000 & 0.000 & 0.00 & 0.00 & 0.00 \\
\hline & Other putrescible & 0.525 & 0.000 & 0.000 & 5.58 & 0.00 & 0.00 \\
\hline & Sub-total & 0.525 & 0.000 & 0.000 & 5.58 & 0.00 & 0.00 \\
\hline \multirow{5}{*}{ Hazardous } & E-waste - ban applicable & 0.176 & 0.001 & 0.002 & 1.87 & 0.02 & 0.02 \\
\hline & E-waste - other & 0.037 & 0.007 & 0.000 & 0.40 & 0.13 & 0.00 \\
\hline & Asbestos & 0.000 & 0.000 & 0.000 & 0.00 & 0.00 & 0.00 \\
\hline & Other hazardous material & 0.110 & 0.003 & 0.000 & 1.16 & 0.06 & 0.00 \\
\hline & Sub-total & 0.323 & 0.012 & 0.002 & 3.43 & 0.22 & 0.02 \\
\hline \multirow{9}{*}{ Other } & Containerised food and liquid & 0.174 & 0.008 & 0.000 & 1.85 & 0.14 & 0.00 \\
\hline & Wood / timber - treated & 0.188 & 0.010 & 0.001 & 2.00 & 0.19 & 0.01 \\
\hline & Wood / timber - untreated & 0.015 & 0.015 & 0.083 & 0.16 & 0.28 & 1.01 \\
\hline & Clothing / textiles & 0.323 & 0.068 & 0.034 & 3.43 & 1.26 & 0.41 \\
\hline & C \& D waste & 0.464 & 0.005 & 0.000 & 4.93 & 0.008 & 0.00 \\
\hline & Nappies & 0.569 & 0.051 & 0.001 & 6.05 & 0.94 & 0.01 \\
\hline & Other waste & 0.203 & 0.028 & 0.001 & 2.16 & 0.52 & 0.01 \\
\hline & Bagged material & -- & 0.638 & 0.008 & -- & 11.88 & 0.09 \\
\hline & Sub-total & 1.938 & 0.822 & 0.127 & 20.60 & 15.30 & 1.54 \\
\hline Total & & 9.408 & 5.371 & 8.249 & 100.0 & 100.0 & 100.0 \\
\hline
\end{tabular}


Table 6. Residual waste (paper, glass, plastic, and metal) stream composition for COGG.

Source: Abridged from EC Sustainability 2018, Tables 53, 84-85

\begin{tabular}{|c|c|c|c|c|c|c|c|}
\hline \multirow[t]{2}{*}{ Sorting Category } & & \multicolumn{3}{|c|}{ Weight (Kg/hh/wk) } & \multicolumn{3}{|c|}{ Percentage (\% by weight) } \\
\hline & & Waste & Recycling & Organics & Waste & Recycling & Organics \\
\hline \multirow{12}{*}{ Paper } & Newspaper & 0.047 & 0.467 & 0.023 & 0.50 & 8.69 & 0.28 \\
\hline & Magazines / brochures & 0.054 & 1.091 & 0.011 & 0.57 & 20.30 & 0.13 \\
\hline & Print / office & 0.088 & 0.178 & 0.000 & 0.94 & 3.31 & 0.00 \\
\hline & Miscellaneous packaging & 0.008 & 0.025 & 0.000 & 0.09 & 0.47 & 0.00 \\
\hline & Disposable paper product & 0.132 & 0.048 & 0.001 & 1.40 & 0.85 & 0.01 \\
\hline & Shredded paper & 0.006 & 0.006 & 0.000 & 0.06 & 0.12 & 0.00 \\
\hline & Other compostable paper & 0.288 & 0.021 & 0.000 & 3.06 & 0.39 & 0.00 \\
\hline & Cardboard - pizza boxes & 0.005 & 0.026 & 0.000 & 0.05 & 0.49 & 0.00 \\
\hline & Cardboard - other & 0.175 & 0.732 & 0.003 & 1.86 & 13.64 & 0.04 \\
\hline & LPB containers - Tetrapak & 0.004 & 0.021 & 0.000 & 0.04 & 0.38 & 0.00 \\
\hline & LPB containers - other & 0.008 & 0.143 & 0.000 & 0.09 & 2.67 & 0.00 \\
\hline & Sub-total & 0.814 & 2.756 & 0.038 & 8.65 & 51.51 & 0.46 \\
\hline \multirow{3}{*}{ Glass } & Glass containers & 0.257 & 0.653 & 0.001 & 2.73 & 12.16 & 0.01 \\
\hline & Glass fines (<12 mm) & 0.035 & 0.334 & 0.000 & 0.37 & 6.23 & 0.00 \\
\hline & Sub-total & 0.292 & 0.988 & 0.001 & 3.10 & 18.39 & 0.01 \\
\hline \multirow{9}{*}{ Plastics } & Plastic containers (1-7) & 0.340 & 0.431 & 0.002 & 3.62 & 8.02 & 0.02 \\
\hline & Other recyclable rigid plastics & 0.021 & 0.027 & 0.000 & 0.22 & 0.51 & 0.00 \\
\hline & Plastic plates, cutlery & 0.011 & 0.001 & 0.000 & 0.11 & 0.02 & 0.00 \\
\hline & Plastic toys, CD / DVD cases & 0.016 & 0.016 & 0.000 & 0.17 & 0.31 & 0.00 \\
\hline & Plastic plant pots & 0.008 & 0.003 & 0.000 & 0.09 & 0.06 & 0.00 \\
\hline & Plastic films & 0.715 & 0.036 & 0.003 & 7.60 & 0.67 & 0.03 \\
\hline & Other rigid plastics - EPS & 0.030 & 0.004 & 0.000 & 0.32 & 0.07 & 0.00 \\
\hline & Other ridge plastics - other & 0.143 & 0.013 & 0.003 & 1.52 & 0.25 & 0.04 \\
\hline & Sub-total & 1.284 & 0.55 & 0.008 & 13.65 & 9.82 & 0.09 \\
\hline \multirow{7}{*}{ Metal } & Steel containers & 0.083 & 0.100 & 0.000 & 0.88 & 0.86 & 0.00 \\
\hline & Steel pots and pans & 0.009 & 0.005 & 0.000 & 0.10 & 0.09 & 0.00 \\
\hline & Aluminium containers & 0.033 & 0.059 & 0.000 & 0.39 & 0.03 & 0.00 \\
\hline & Aluminium foil & 0.037 & 0.002 & 0.000 & 0.39 & 0.03 & 0.00 \\
\hline & Other metal - steel & 0.044 & 0.031 & 0.002 & 0.47 & 0.58 & 0.02 \\
\hline & Other metal - non-ferrous & 0.027 & 0.016 & 0.000 & 0.28 & 0.30 & 0.00 \\
\hline & Sub-total & 0.232 & 0.213 & 0.002 & 2.47 & 3.97 & 0.02 \\
\hline
\end{tabular}

The waste profile results were further broken into a) recovered, and b) unrecovered resources, as shown below in Table 7 and Table 8.

COGG is currently hosting a total recovery rate of $74.62 \%$ on all wastes, as documented in Table 8.

One reason why COGG does not have a higher waste recovery rate is because of its contamination rate. The contamination rate is calculated using the following formula:

The percentage of the recycling bin (or organics bins) contents not accepted, Weight of material not accepted in the recycling bins or (organics bins) $\times 100$ Total weight of recycling bins (or organic bins) contents

The current COGG contamination rate is $18.80 \%$ of the total waste volume, as explained in Table 9.

A sample of the GIS output arising from this modelling is depicted below in Figure 4, that depicts the monthly totals per mesh block for existing buildings. Figure 5 shows the monthly municipal solid waste totals per mesh block. The totals range from 0 to $28,111 \mathrm{kgs}$ of municipal solid waste per month for each mesh block.

Mesh Blocks (ABS 2020a) are the smallest geographical / statistical area defined and used by the Australian Bureau of Statistics (ABS). Mesh blocks form the building blocks for the larger regions of the Australian Statistical Geography Standard (ASGS) (ABS 2020b). All other statistical areas or regions are built up from, or approximate by whole Mesh Blocks. Mesh Blocks broadly identify land use, such as residential, commercial, primary production and parks, etc. (ABS 2020a).

The recycling activities for COGG are shown in Figure 6. As indicated up to 5,349 kilograms of waste in a Mesh block is being recycled. 
Table 7. COGG: Unrecovered resources in the waste bin. Source: Abridged from EC Sustainability 2018, Tables 54, 86

\begin{tabular}{|c|c|}
\hline Material Category & Percentage (\% by weight) \\
\hline Recyclable paper & 5.53 \\
\hline Recyclable glass & 2.73 \\
\hline Recyclable plastics & 4.21 \\
\hline Recyclable steel packaging & 0.98 \\
\hline Recyclable aluminium packaging & 0.74 \\
\hline MGB recyclable & 14.19 \\
\hline Other steel & 0.47 \\
\hline Other non-ferrous & 0.28 \\
\hline Potentially recyclable & 0.75 \\
\hline Food & 34.00 \\
\hline Garden organics & 8.52 \\
\hline Other organic & 5.74 \\
\hline Compostable & 48.26 \\
\hline Non-recyclable paper & 3.12 \\
\hline Non-recyclable glass & 0.37 \\
\hline Non-recyclable plastics & 9.44 \\
\hline Total other & 23.87 \\
\hline MGB non-recyclable & 36.80 \\
\hline Total & 100.00 \\
\hline
\end{tabular}

Table 8. Geelong Recycling resource recovery rates. Source: Abridged from EC Sustainability 2018

\begin{tabular}{|c|c|}
\hline Material category & Resource recovery rate (\% by weight) \\
\hline Recyclable paper and cardboard & 83.09 \\
\hline Recyclable glass & 71.79 \\
\hline Recyclable plastic containers (1-7) & 44.03 \\
\hline All recyclable plastic materials types & 54.75 \\
\hline Recyclable steel & 53.38 \\
\hline Recyclable aluminium & 46.60 \\
\hline Total & 74.63 \\
\hline
\end{tabular}

Table 9. Geelong: Recycling stream contamination rate. Source: Abridged from EC Sustainability 2018, Table 55, 87

\begin{tabular}{|c|c|c|}
\hline Material category & & Percentage (\% by weight) \\
\hline Compliant & MGB recyclable & 74.98 \\
\hline \multirow{3}{*}{ Containing - excluding glass fines } & Potentially recyclable & 0.88 \\
\cline { 2 - 3 } & Compostable & 1.18 \\
\cline { 2 - 3 } & MGB non-recyclable & 16.74 \\
\cline { 2 - 3 } & Total contamination & 18.80 \\
\hline Potential contamination & Glass fines & 6.23 \\
\hline
\end{tabular}

\section{ORGANIC WASTE}

The diversion and recovery of organic waste is one of the most significant opportunities and challenges for reducing the environmental impacts of waste disposal, generally and in COGG. Organic materials (food, garden, timber, textiles and paper) typically contribute around at least $50 \%$ of household garbage by weight, $25-30 \%$ of industrial waste, and make up over $25 \%$ of all waste landfill in Victoria. The financial and environmental costs of managing these wastes are high (Blue Environments 2020).
Landfill organics contribute to emissions of potent greenhouse gas methane, as well as producing toxic leachate that contaminates groundwater and releases odoriferous toxic gases at the landfill surface. To lessen these impacts and risks, landfills require expensive engineering and management controls and decades of monitoring and management after the landfill closes. The wastes in a landfill will continue to pose environmental risks for future generations, for many decades, and even for centuries. For most local municipalities, the greenhouse gas emissions from the waste they collect, and landfills, are by far the most significant source of emissions from all their municipal operations, including street lighting (Blue Environments 2020). 


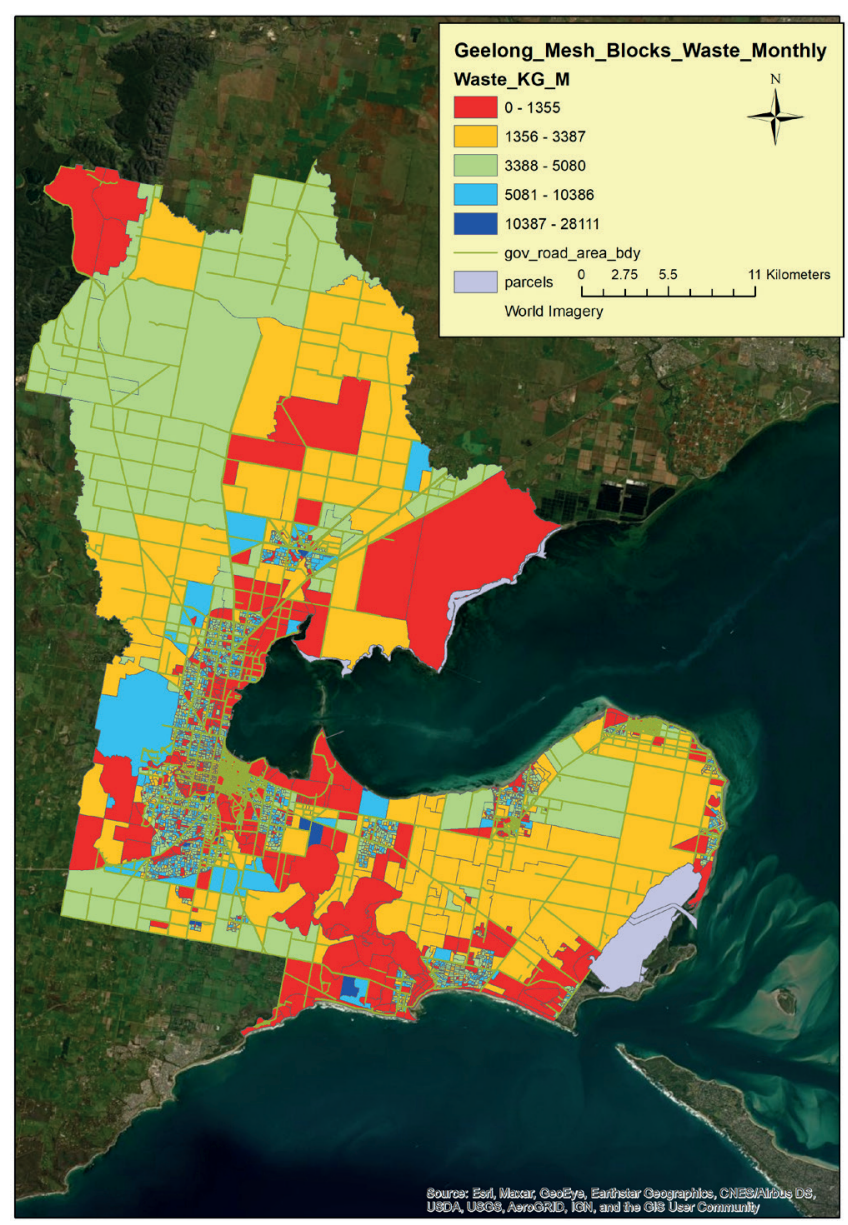

Fig. 4. COGG Monthly Residential Waste by Mesh block

Landfilled food and wet garden organics have the potential to release methane with a global warming potential equivalent to just under 2 tonnes $\mathrm{CO}_{2}$ per tonne of organics. Although landfill gas management practices have improved compared to what they historically were in the past, even landfills with high levels of post cell closure gas management still do not capture all gas. Food organics and 'wet' green waste degrade rapidly and around 40-50\% of the methane they generate in landfill can and are emitted in the first 2 to 3 years after such waste is buried or capped/ covered. This means that generally, most emissions from a landfill site can be released to the atmosphere before effective gas recovery systems are in place. Thus, even a high performing landfill capturing $80 \%$ of gas generated after cell closure, can see around $700-900 \mathrm{~kg}$ of $\mathrm{CO}_{2}$ equivaent methane released to the atmosphere per tonne of landfill food and wet garden organics. Composting facilities generate some greenhouses gases - on average, about $50-60 \mathrm{~kg} \mathrm{CO}$-e/tonne of organics processed. Transporting organics generates some greenhouse gas emissions - but at the low rate of around 65 grams/tonne/ km (Blue Environments 2020).

Barwon Waste Recovery in 2020 undertook a market assessment as to the viability for recycled organic products within the region (Blue Environments 2020).

The assessment identified two options for organic waste: 1. Organic Renewable Option 1: using composting techniques on organic waste to produce a series of fertilizer products for commercial, agricultural and residential uses.

2. Organic Renewable Option 2: to develop an anaerobic digester that will convert organic wastes into biogas or methane that can be used as a renewable fuel source.

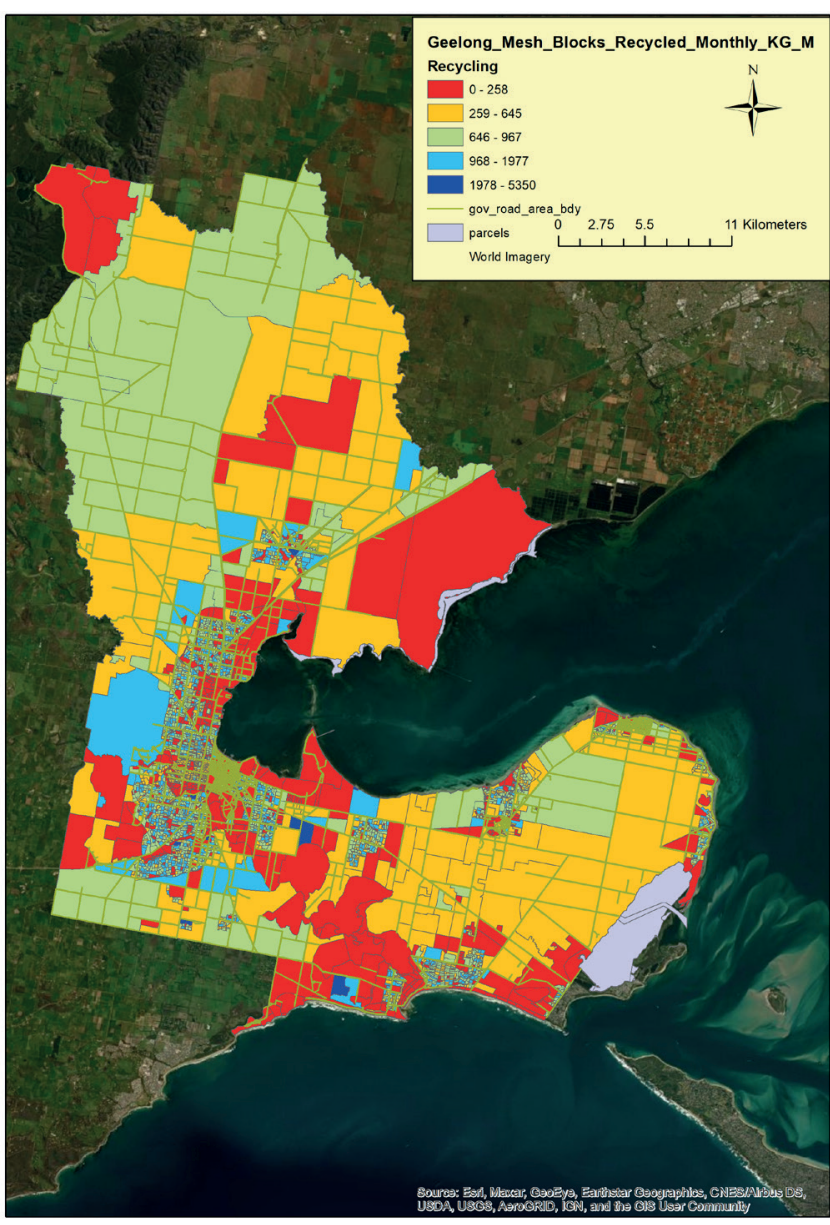

Fig. 5. COGG Monthly Recycling totals by Mesh blocks

Organic Renewable Option 1

As stated in the Barwon Waste Recovery commissioned Organics End Markets Study (Blue Environments 2020), if COGG and the neighbouring (to the immediate south) Surf Coast Council introduced a food organic/garden organics (FOGO) service it was projected that organics recovery in those two municipalities would increase from the current 41,000 tonnes per year to over 80,000 tonnes by 2030. Across the larger Geelong / and Bellarine Peninsula region, the quantities of recovered municipal organics could be expected to increase from under 50,500 tonnes per year to over 90,000 tonnes per year by 2030 (Blue Environments 2020).

If all of these wastes were converted into compost, fertiliser, and mulch products, rather than energy, they could expect to yield in the order of:

- 70,000-75,000 tonnes of soil conditioner compost or organic fertiliser products (including some dried and composted biosolids from other areas);

- 45,000-50,000 tonnes of mulch (mainly timber mulches); - $\quad$ around 5,000 tonnes of woody 'oversize' screening from composting facilities that currently has no market but may be suited to bioenergy and/or biochar production; and

- 115,000-120,000 tonnes of dried biosolids used as fertiliser or potentially bioenergy. Source: Blue Environments 2020).

At present, and in the foreseeable future, composting is the most likely option for the recovery of garden organics (GO), FOGO and commercial and industrial putrescible organics (Blue Environments 2020). This is likely to be supplemented by thermal energy recovery from timber and woody waste, and Anaerobic digestion of wet wastes. However, it is envisaged that the main market development needs will be for compost and related products. 


\section{Organic Renewable Option 2}

This method proposes to develop anaerobic digestion that will convert organic wastes into biogas or methane that can be used as a renewable fuel source.

The Organics End Markets Study (Blue Environment 2020) outlined an argument for energy recovery from industrial organics via anaerobic digestion. Barwon Water's Colac facility creates an opportunity for some other industrial organics to be delivered to the facility. This is now occurring using food and other organics from meat processors from the Colac region. The facility, Renewable Organics Network, is being built in nearby Colac to use high-strength organic waste from the Australian Lamb Company (ALC) and the Bulla Dairy Foods factories for the production of electricity and hot water. The project is expected to create 17 construction jobs and 45 ongoing jobs.

Other benefits of the Renewable Organics Network Colac project include: the net production of 5.5 gigawatt hours of renewable electricity each year; approximately $50 \%$ of this renewable electricity will be used "behind-themeter" to take the Colac Water Reclamation Plant off-grid electricity; the remaining renewable electricity generated will be exported into the grid; renewable hot water will also be generated by the project and supplied to ALC via an innovative hot water pipeline, which offsets ALC's natural gas consumption from the grid by 21.4 terajoules each year - equivalent to the gas usage of 350 households; and, overall, the generation of dispatchable renewable energy in the form of hot water and electricity results in carbon emissions being reduced by 6,300 tonnes each year (Barwon Water 2020). The report states that other food, dairy and meat processors in other parts of the

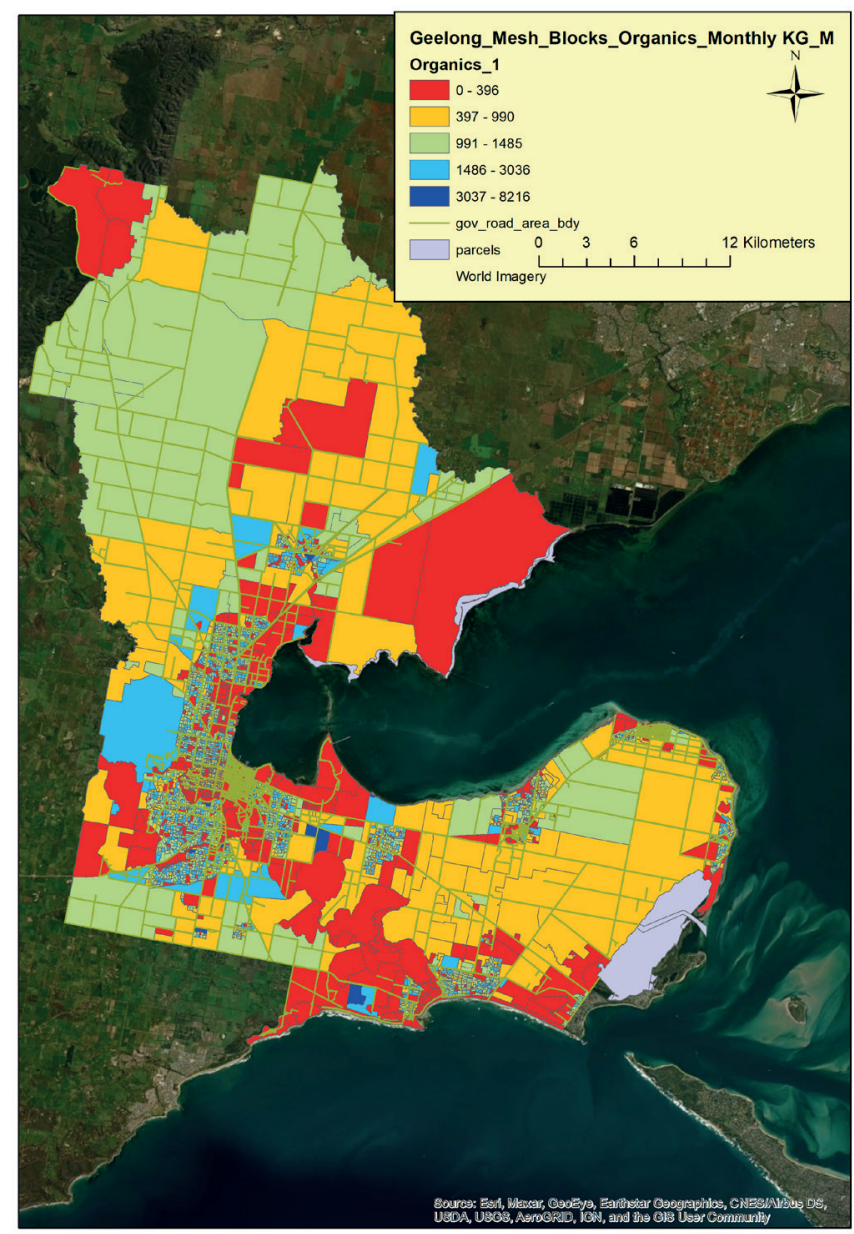

Fig. 6. COGG Monthly Organic Waste by Mesh Block region (Warrnambool, Geelong, and potentially Hamilton; all communities inside the Barwon Waste Recovery region) may also be able to develop comparable facilities.

In terms of COGG, seven different biogas economic and financial models were selected to determine the economic viability of a biogas plant for Geelong. The analysis was based upon the Barwon Waste Recovery bin audit report of 2018 (University of South Wales 2020). The seven models ranged from very simple to use to highly detailed spreadsheets that were comprised several thousand lines of coded formulas and data entry points.

For this article two exemplar models were selected for further examination:

1. the Biogas Calculator from Ireland/Wales

2. the Anaerobic Project Screening model from the US EPA.

The Biogas Calculator document provides a guide to Irish Farmers to assess the feasibility of developing anaerobic digestion facilities on their farms, where manures (cattle, pig, poultry), organic municipal waste, food industry waste, animal by-products, catering waste and sewage sludge and specifically grown crops, such as maize, can be processed anaerobically (University of South Wales 2020).

The Biogas Calculator looks at seven potential biogas sources (households, agricultural industry waste, sludge, energy crops, catering waste, waste generated by industry and harvested biomass. For this paper we only used the household waste category (University of South Wales 2020). The Biogas Calculator required two inputs to calculate the potential biogas output for COGG, the population of COGG and the amount of organic waste per person per year.

The potential biogas production, when converted to kilowatt-hours, represents 24,419,241 potential kilowatthours. This number of kilowatts has a potential revenue value of AU\$5.9 million per annum. The \$ value was calculated by multiplying the kilowatt total by the average official electricity price per kWh by the Victorian state government reported by the CANSTAR energy reporting agency (GOGG 2020).

The Anaerobic Project Screening model tool uses a MassBalance Methodology to estimate biogas and digestate production. This is a commonly applied methodology that examines the products from the anaerobic digestion of solid wastes. Solid wastes entering the digester consist of organic material, inorganic constituents and water. During the digestion process a fraction of the volatile solids is converted into biogas consisting of primarily methane and carbon dioxide. Other compounds present in the biogas, such as hydrogen sulfide, are important but often considered negligible for this framework when calculating the production of biogas.

The program has eight major different categories of feedstock: fruit and vegetable, livestock excreted, other organic municipal, kitchen and food scrap, energy and cash crops garden, dairy and seafood). The major categories are further segmented into 80 subcategories. For the Geelong calculation nine subcategories were used (diverted municipal waste, grass, wood, textiles, newspaper, cardboard, magazines, folding cartons and paper bags).

The Anaerobic Project model program calculated the annual biogas production at 4,542,973 $\mathrm{m}^{3} /$ year or the refined methane production to be 2,266,943 $\mathrm{m}^{3} /$ year. The potential biogas production, when converted to kilowatthours, represented 47,928,365 potential kilowatt-hours. This number of kilowatts has a potential revenue value of AU\$11.6 million per annum. The \$ value was calculated by multiplying the kilowatt total by the average official 
electricity price per kWh by the Victorian state government reported by the CANSTAR energy reporting agency [34].

In addition to this new revenue stream, COGG would reduce its carbon footprint by 3,798 metric tons.

\section{DISCUSSION}

The result of the two selected models showcases that COGG has a greater opportunity to derive sizeable benefits from using organic waste from households. With the option of creating Anaerobic digesters, as is demonstrated after simulating the two adopted calculation model (the Biogas Calculator model borrowed from Ireland / Wales, and the Anaerobic Project Screening model from the US EPA, it is now clear that the COGG can maximize its energy production. For instance, with the Biogas Calculator model, the simulation shows that there is a potential to produce over 2.3 million cubic metres of biogas which, when converted electric energy would equate to over 24.4 million kWh yielding local government with over AU\$5.9 million yearly.

An almost similar output is viable with the Anaerobic Project Screening Model that is shown to promise over $21,788 \mathrm{mWh}$ and a renewable natural gas capacity of $2,266,943 \mathrm{~m}^{3}$ yearly. Calculations using this model also shows that organic waste generated in COGG could yield over 4.5 million $\mathrm{m}^{3}$ yearly of biogas which when refined could translate to over 2.3 million $\mathrm{m}^{3}$ of refined methane gas. Such would go a long way in reducing emissions as they could serve a sizeable number of households in the city.

Such figures obtained from these two models as very significant noting that the COGG has already pooled together with like-minded Victorian councils that are looking forward to transitioning to $100 \%$ use of renewable energy (COGG 2019). With such renewable energy programs, the councils are projecting to benefit from financial savings as well as guarantee long-term energy certainty, which is not obvious with relying on nonrenewable sources.

Besides the revenue generation, the two models have been shown to rely on feedstock from obvious wastes that are generated in great capacity in COGG, and which have also not been given much attention when it comes to recycling and recovery. In particular, the organic materials from different sources have been reported to constitute more than $50 \%$ of the total waste that find their ways in landfills in the Victorian region, and these, as noted with the Biogas Calculator have potential to produce substantial biogas; thus, helping not only in reducing the emissions from those landfills but also help in contributing to environmental sustainability as well as economic growth.

With the option of composting the organic waste, COGG would have diverse options of boosting its agricultural sector through the various fertilizer products that could be derived from wastes. In addition, following the substantial amount of organic waste that COGG region is associated with, it is also probable that some of the fertilizer products could be sold to other regions; hence, contributing to revenue flow for the councils. This approach of composting the waste as has been noted by Blue Environments (2020) is not only viable for fertilizer production, but also has a potential to produce energy, especially from the 'oversize' woody wastes that cannot be used as fertilizers. This means that composting option also has the potential to contribute in the Victorian council's objective of using 100\% clean energy (COGG 2019). The adoption of the composting initiative also impacts positively on businesses, especially as is noted after the pilot programs conducted in the Australian states of Queensland, Western Australia and South Australia. From the pilot studies, it was noted that besides reducing the amount of waste find its way into landfills, the businesses in the areas were also benefiting as this strategy allowed them to avert transportation costs and landfill fees. Additionally, these pilots also opened opportunities for stakeholders drawn from different sectors to propose programs and tools, like the Dynamic Resource Efficiency Calculation Tool developed by the Royal Melbourne Institute of Technology (Australia 2020), aimed at helping stakeholders in selfassessing their organic waste practices.

In the context of utilizing organic waste as a source of revenue generation, as has been focused in this paper, the adoption of a composting model would serve COGG well. This is because, as shown above, organic wastes are the least recycled and/or recovered waste categories in the Victorian region. However, this option would face challenges since the cost of landfills in Australia are relatively cheaper (Australia 2020), and it would require councils to come up with proactive and innovative ways of incentivising the public to encourage them to divert their wastes from landfills. It would also be less effective as other wastes would not be composted; hence, requiring additional methods of management. In this case, the anaerobic digester may seem much appropriate as it has the potential to allow management of a wide range of organic wastes. It also produces a higher annual biogas output; hence, ensuring that local councils can earn higher revenue values as well as reduce substantial amounts of emissions. While this study focusses on a specific case study, the methods developed in the present paper can be applied to other urban contexts in varying geographical locations, leading to a better understanding of waste management options for more informed decisions; hence aiding at governance levels regarding urban waste management and disposal.

\section{CONCLUSIONS}

Through this paper exploring the organic waste of the City of Greater Geelong (COGG) through two scenarios -with the use of GIS systems, the current and future waste profiles for the COGG were outlined. This demonstrated positive results and the underlined the potential for GISbased system in modelling and evaluating prospective energy derived from green waste. The system showcased that there is potential to visualize commercial, industrial, construction and demolition waste streams. This visualization feature, coupled with the build-out provisions, could conceptualize future waste streams and assist in the understanding and estimating quality implementations of a more efficient and innovative waste hierarchy; comprised of three guiding principles: avoidance, resource recovery, and disposal.

Table 10. Forecast COGG BioGas Production Calculated by the BioGas Calculator. Source: University of South Wales 2020

\begin{tabular}{|c|c|c|c|c|}
\hline \multicolumn{3}{|c|}{ Energy Potential of Organic Waste Generated by households } \\
\hline Region & Population & Organics waste / person / year $(\mathrm{kg})$ & $\begin{array}{c}\text { Average BioGas per ton of treated } \\
\text { waste }\left(\mathrm{m}^{3}\right)\end{array}$ & ${\text { Potential BioGas production }\left(\mathrm{m}^{3}\right)}^{3}$ \\
\hline COGG & 257,180 & 60 & 150 & $2,314,620$ \\
\hline
\end{tabular}


The literature underlined that the concept and application of GIS focusing on waste in Australia is still in its early stages, but this is expected to develop rapidly noting the challenges of scale coupled with the rapid urbanisation rate. Indeed, as the volumes of waste continue to grow, the pressure on society and cities to control that growth will continue to escalate, demanding urgent and efficient models for waste management. The approach for this paper is thus topical and can be replicated to varying contexts, where we showcase that waste information calibrated into a GIS, with associated modelling, offers an important possible new tool that can assist to inform and manage the growing amounts of municipal waste.

\section{ACKNOWLEDGEMENTS}

The authors wish to acknowledge the advice of the journal Editorial Committee in revisions for this article, and also staff at the Barwon South West Waste and Resource Recycling Group (BSWRRG) in providing technical and statistical data that underpin much of these calculations and research. As a declaration, the authors have no beneficial interests in the City of Greater Geelong Council nor the BSWRRG.

\section{REFERENCES}

Allam Z. and Jones D.S. (2018). Towards a Circular Economy: A Case Study of Waste Conversion into Housing Units in Cotonou, Benin. Urban Science 2: 1-19.

Australia (2017). How food waste is managed in Australia. Available at: https://www.environment.gov.au/protection/waste-resourcerecovery/publications/infographic-how-food-wate-is-managed-in-australia [Accessed 1 October 2020].

Barwon South West Waste and Resource Recycling Group (BSWWRRG). (2016). Barwon South West Waste and Resource Recovery Implementation Plan 2017-2026. Available at: https://www.bswwrrg.vic.gov.au/wp-content/uploads/2017/07/BSW-Implementation-Plan29062017sml.pdf [Accessed 1 October 2020].

BSWWRRG (2019). Annual Report 2018/2019. Available at: https://resources.reduce-recycle.com.au/bswwrrg/wp-content/ uploads/2019/10/22054541/Final-Annual-Report-2018-2019.pdf [Accessed 1 October 2020].

Barwon Water (2020). Renewable Organics Network. Available at: https://www.reduce-recycle.com.au/.

Blue Environments (2020). Organic End Markets Study. Docklands, Vic: Blue Environments. Available at: https://www.canstarblue.com. au/electricity/electricity-costs-kwh/ [Accessed 1 October 2020].

CANSTAR (2020). Average Electricity Costs per kWh. Available at: https://www.canstarblue.com.au/electricity/electricity-costs-kwh/ [Accessed 1 October 2020].

Carey A. (2017). What a waste: Victoria's rubbish pile projected to hit 20 million tonnes a year. Available at: https://www.theage.com. au/national/victoria/what-a-waste-victorias-rubbish-pile-projected-to-hit-20-million-tonnes-a-year-20170803-gxot6x.html [Accessed 1 October 2020].

City of Greater Geelong (GOGG) (2019). City joins bulk renewable program. Available at: https://www.geelongaustralia.com.au/ environment/news/item/8d74b1a3375d82d.aspx?__ [Accessed 1 October 2020].

CommunityViz (2020) CommunityViz Explained. Available at: https://communityviz.city-explained.com/ [Accessed 1 October 2020].

Duan N., Tian H., Lin C., Zhang Y. and Liu Z. (2018). Comparing two enhancing methods for improving kitchen waste anaerobic digestion: Bentonite addition and autoclaved de-oiling pretreatment. Process Safety and Environmental Protection 115: 116-124.

EC Sustainability (2018). Regional Kerbside Waste Audit. North Sydney, NSW: EC Sustainability.

EPA (2015). Global Non-CO2 Greenhouse Gas Emission Projections \& Mitigation Potential: 2015-2050. Washington DC: EPA.

Frontier AG \& Environment (2018). Grampians Organics Review: Prepared for Grampians Central West Waste and Resource Group.

Global Methane Initiative (GMI) (2020). Australia. Available at: https://www.globalmethane.org/partners/partner.aspx?c=australia [Accessed 1 October 2020].

Herron M., Roös P.R., Donley C. and Jones, D.S. (2015). Geographic information systems and coastal planning in Australia. Geography Environment Sustainability (Russian Geographical Society) 8: 79-99.

Jones D.S. and Roös P.B. (2019). Geelong: Djilang - A Tapestry of Histories, Voices and Ecologies. In: Jones DS and Roös PB (eds) Geelong's

Changing Landscape: Ecology, Development and Conservation. Melbourne: CSIRO Publishing, 1-8.

Kaza S., Yao L.C., Perinaz B-T. and Van Woerden F. (2018). What a Waste 2.0: A Global Snapshot of Solid Waste Management to 2050. Washington DC: World Bank.

Matsakas L., Kekos D., Loizidou M. and Christakopoulos P. (2014). Utilization of household food waste for the production of ethanol at high dry material content. Biotechnology for Biofuels 7: 4 .

Melbourne Water (2020). Western Treatment Plant. Available at: https://www.melbournewater.com.au/water-data-and-education/ learning-resources/water-and-sewage-treatment-plants/western-treatment [Accessed 1 October 2020].

MetroTunnel (2020). Soil Management. Available at: https://metrotunnel.vic.gov.au/construction/construction-impacts/soilmanagement and https://metrotunnel.vic.gov.au [Accessed 1 October 2020].

Prussi M., Padella M., Conton M., Postma E.D. and Lonza L. (2019). Review OfTechnologies For Biomethane Production And Assessment Of EuTransport Share In 2030. Journal of Cleaner Production 222, 565-572.

Schuchmann K. and Müller V. (2016). Energetics and Application of Heterotrophy in Acetogenic Bacteria. Applied and Environmental Microbiology 82, 4056-4069.

Stensholt J. (2015). Billionaire Anthony Pratts' US purchase also to boost Visy in Australia. Available at: https://www.afr.com/companies/ manufacturing/billionaire-anthony-pratts-us-purchase-to-also-boost-visy-in-australia-20150414-1 mkgvw [Accessed 1 October 2020].

Stensholt J. (2017). Anthony Pratts hails $\$ 2$ b Australian expansion as it talk with Amazon. Available at: https://www.afr.com/companies/ manufacturing/anthony-pratts-visy-hails-2b-australian-expansion-as-it-talks-with-amazon-20170822-gy19q0 [Accessed 1 October 2020]. University of South Wales (2020). Bio gas calculator. Wales: University of South Wales and Waterford council.

United Nations (2016). Final list of proposed Sustainable Development Goal indicators. Available from: https://sustainabledevelopment. un.org/content/documents/118030fficial-List-of-Proposed-SDG-Indicators.pdf [Accessed 1 October 2020].

United Nations. (2020). Sustainable development goals. https://www.un.org/sustainabledevelopment/sustainable-developmentgoals/ [Accessed 1 October 2020]. 
Vedelago C., Houston C. and Ilanbey S. (2019). Toxic waste stockpile found in rubble of burnt-down warehouse. Available at: https:// www.theage.com.au/national/victoria/toxic-waste-stockpile-found-in-rubble-of-burnt-down-warehouse-20191020-p532fy.html [Accessed 1 October 2020].

Victoria (1970). Environment Protection Act 1970. Available at: https://www.legislation.vic.gov.au/in-force/acts/environment-protectionact-1970/213 [Accessed 1 October 2020].

Victoria (2018). Guide to biological recovery of organics. Melbourne: Sustainability Victoria.

Victoria (2020a). Victorian Spatial Data Mart. Available at: http://services.land.vic.gov.au/SpatialDatamart/.

Visy Industries (2020). Visy Recycling. Available at: https://www.visy.com.au/recycling/about [Accessed 1 October 2020].

Walker D. (2011). CommunityViz the essential tool for a new generation of planning, Chicago, IL: Planners Press. 